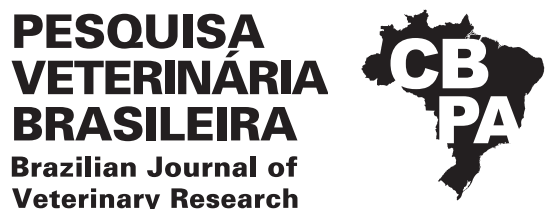

Pesq. Vet. Bras. 40(12):970-976, December 2020 DOI: 10.1590/1678-5150-PVB-6679

Original Article Veterinarv Research

ISSN 0100-736X (Print) Livestock Diseases

ISSN 1678-5150 (Online)

\title{
Use of oral fluids to detect anti Lawsonia intracellularis antibodies in experimentally infected pigs ${ }^{1}$
}

\author{
Michelle P. Gabardo², José Paulo H. Sato², Talita P. Resende², Luisa V.A. Otoni², \\ Lucas A. Rezende², Amanda G.S. Daniel ${ }^{2}$ (D) , Carlos E.R. Pereira ${ }^{2}$ \\ and Roberto M.C. Guedes ${ }^{2 *}$ (D)
}

\begin{abstract}
Gabardo M.P., Sato J.P.H., Resende T.P., Otoni L.V.A., Rezende L.A., Daniel A.G.S, Pereira C.E.R. \& Guedes R.M.C. 2021. Use of oral fluids to detect anti-Lawsonia intracellularis antibodies in experimentally infected pigs. Pesquisa Veterinária Brasileira 40(12):970-976. Departamento de Clínica e Cirurgia, Escola de Medicina Veterinária, Universidade Federal de Minas Gerais, Av. Antônio Carlos 6627, Belo Horizonte, MG 31270-901, Brazil. E-mail: guedesufmg@gmail.com

Several pathogens and antibodies derived from serum or produced in tissues associated with the oral cavity are present in the oral fluid (OF). Considering the applicability of this alternative sample, recent studies in veterinary medicine have tested $\mathrm{OF}$ as a replacement for serum in diagnostic assays. The aim of this study was to standardize the immunoperoxidase monolayer assay (IPMA) to detect anti-Lawsonia intracellularis immunoglobulin A (IgA) and immunoglobulin G (IgG) in OF samples from experimentally infected pigs. Sixty-two pigs were divided into two groups: control ( $\mathrm{T} 1, \mathrm{n}=30$ ) and inoculated with L. intracellularis $(\mathrm{T} 2, \mathrm{n}=32)$. Blood, OF and fecal samples were collected at $0,7,14,21,28$ and 42 days post-inoculation (dpi). Some adaptations of the standard technique for serum were made to IPMA for the detection of IgA and IgG in OF. The IPMA showed high specificity and sensitivity for serum samples and high specificity and moderate sensitivity for the detection of IgA and IgG in OF. There was high agreement between the results of serum IgG and OF IgA and IgG. Based on our results, oral fluid samples may be used for the evaluation and determination of anti-L. intracellularis antibodies in pigs, but not for individual diagnosis of swine proliferative enteropathy.
\end{abstract}

INDEX TERMS: Oral fluid, Lawsonia intracellularis, antibody, pigs, diagnostic, enteric disease, porcine proliferative enteropathy, serology, swine.

\begin{abstract}
RESUMO.- [Utilização de fluidos orais para deteç̧ão de anticorpos anti Lawsonia intracellularis em suínos experimentalmente infectados.] Vários patógenos e anticorpos derivados do soro ou produzidos em tecidos associados a cavidade oral estão presentes no fluido oral (FO). Considerando a aplicabilidade dessa amostra alternativa, estudos recentes em medicina veterinária têm testado o FO como substituto do soro para testes diagnósticos. 0 objetivo desse estudo foi padronizar a imunoperoxidase em monocamada

\footnotetext{
${ }^{1}$ Received on July $11,2020$.

Accepted for publication on September 4, 2020.

${ }^{2}$ Departamento de Clínica e Cirurgia, Escola de Medicina Veterinária, Universidade Federal de Minas Gerais (UFMG), Av. Antônio Carlos 6627, Belo Horizonte, MG 31270-901, Brazil. E-mails: michelle.gabardo@ifmg.edu.br, jose.sato@agroceres.com, talitaresendevet@gmail.com, luisavianna.vet@gmail.com, rezendeavelino65@gmail.com, amandavet2007-1@hotmail.com,carlos.pereira@ufv.br *Corresponding author: guedesufmg@gmail.com
}

de célula (IPMC) para a detecção de imunoglobulina A e imunoglobulina $\mathrm{G}$ anti-Lawsonia intracellularis em amostras de FO de suínos experimentalmente infectados. Um total de 62 suínos foram divididos em dois grupos: controle (T1, $\mathrm{n}=30$ ) e inoculados com L. intracellularis ( $\mathrm{T} 2, \mathrm{n}=32$ ). Sangue, FO e amostras de fezes foram coletados aos 0, 7,14, 21, 28 e 42 dias após a inoculação (dpi). Algumas adaptações da técnica foram realizadas na técnica padrão da IPMC para a detecção de IgA e IgG. A IPMC demostrou alta especificidade e sensibilidade para amostras de soro e alta especificidade de moderada sensibilidade para a detecção de IgA e IgG em FO. Houve alta concordância entre resultados de detecção de IgG em soro com a IgA e IgG em amostras de FO. Baseado em nossos resultados, amostras de fluido oral podem ser usadas em avaliações e detecção de anticorpos anti-L. intracellularis em suínos, porém não de forma individual.

TERMOS DE INDEXAÇÃO: Fluido oral, anticorpo, Lawsonia intracellularis, suínos, diagnóstico, doenças entéricas, enteropatia proliferativa, sorologia. 


\section{INTRODUCTION}

Lawsonia intracellularis is an obligate intracellular bacterium that causes porcine proliferative enteropathy (PPE) (McOrist et al. 1995). PPE is an intestinal infectious disease of growfinishing pigs. PPE has three manifestations: acute, characterized by bloody diarrhea and death of the pigs at slaughter age; chronic, characterized by a performance decrease and transitory diarrhea in pigs from 6 to 20 weeks of age; and subclinical, characterized mainly by decreased production performance (Guedes 2007).

Among ante mortem diagnostic tests, PCR is highly specific; however, there are inhibitory factors that interfere with sensitivity in fecal samples. Additionally, the results are influenced by the course of the disease and variations in fecal shedding (Vannucci et al. 2012). Serological tests, such as ELISA, indirect immunofluorescence and the immunoperoxidase monolayer assay (IPMA), are also used (Kroll et al. 2005). Seroconversion occurs approximately 14 days after exposure to the agent and lasts for a long period; serology can be used to evaluate the kinetics of infection in the herd and to establish disease control strategies (Walter et al. 2004).

Traditionally, serum is used in diagnostic tests, but there are an increasing number of studies in veterinary medicine that used oral fluid (OF) to detect viruses, bacteria and specific antibodies against these agents (Prickett et al. 2008). OF samples may provide practical and economic advantages, including easier collection and reduced stress (Prickett \& Zimmerman 2010).

Additionally, several studies have shown a high correlation between the detection of infectious agents and antibodies from serum and OF (Kittawornrat et al. 2013, Panyasing et al. 2014, 2013). Tests based on OF have demonstrated good sensitivity, specificity and reproducibility (Kittawornrat et al. 2013, Ouyang et al. 2013). To date, there have been no reports of the use of OF to detect anti-L. intracellularis antibodies in experimentally infected pigs. This study aimed to detected immunoglobulin A (IgA) and immunoglobulin G (IgG) anti- $L$. intracellularis antibodies in OF and to verify the persistence of the detection of these isotypes in OF in experimentally infected pigs. ${ }^{e}$

\section{MATERIALS AND METHODS}

Animals and experimental design. The experiment was approved by the Animal Experimentation Ethics Committee of the "Universidade Federal de Minas Gerais" (\#77/2011 - June 8, 2011). Sixty-two 5-week-old pigs $(10.0 \pm 0.64 \mathrm{~kg} / \mathrm{b} . w$.$) from a commercial$ swine herd free of clinical signs of PPE and other enteric diseases were used. All pigs were weighed, ear-tagged and randomly divided into the control (T1) and infected (T2) groups (30 and 32 pigs each, respectively). Each group was housed in separated rooms with four suspended pens with plastic floors, meshed-wired separations, deposit feeders and nipple drinkers. Four pigs were grouped per pen; however, there were only three pigs in two pens of the T1.

Management of temperature, and feeding were the same for all pens. All daily management activities were initially performed in control rooms, changing boots and overalls between the control room and infected challenge pigs. No parenteral or feed antimicrobial agents were used throughout the experimental period.

At 42 days post inoculation (dpi), all pigs were individually weighed. Pigs in poor clinical condition were euthanased and necropsied. The remaining pigs were euthanased and postmortem evaluated at $49 \mathrm{dpi}$. At necropsy, gross lesions were evaluated and ileum and cecum samples were collected to histopathologic and immunohistochemistry (IHC) to confirm Lawsonia intracellularis infection (Guedes et al. 2002a). For the IHC the labeled streptavidin ${ }^{3}$ method with polyclonal antibodies specific for $L$. intracellularis was used (Guedes \& Gebhart 2003a).

Preparation of inoculum and inoculation. The inoculum was prepared from porcine intestines affected by PPE, according to a previously described model (Guedes et al. 2002c). On day 0, pigs in T2 received 1 dose of $60 \mathrm{~mL}$ of the inoculum via stomach tube. The total dose was approximately $8.8 \times 10^{10} \mathrm{~L}$. intracellularis/pig. Pigs in T1 received a sham inoculum. Bacteriologic testing of the inoculum did not detect any other confounding enteropathogenic organisms, such as Salmonella sp., Brachsypira spp. or enteropathogenic Escherichia coli.

Clinical evaluation and sample collection. Clinical observations of diarrhea were made by the same person twice a week. The scoring was based on Guedes et al. (2002d). The OF, blood and fecal samples were collected individually $0,7,14,21,28,35$ and $42 \mathrm{dpi}$. The pen OF sample was collected $0,4,14,21,28,35$ and $42 \mathrm{dpi}$. To collect $\mathrm{OF}, 15 \mathrm{~cm}$ long cotton ropes were individually provided for pig. To prevent other pigs in the pen to have access to the rope of a given individual, the cotton ropes were marked and provided directly into the mouth of the animal. To collect pen samples, rope bundles were tied to the side of each pen for a time period sufficient to acquire an average of $10 \mathrm{~mL}$ of OF per pen or until the pigs lost interest in the rope, in general for $30 \mathrm{~min}$. OF were extracted by twisting the damp part in plastic bags, then transferring to $50 \mathrm{~mL}$ conical tubes, centrifuged at $1000 \mathrm{xg}$ for $10 \mathrm{~min}$, aliquoted and stored at $-20^{\circ} \mathrm{C}$ until tested. Blood samples were collected at the same days, processed and serum stored at $-20^{\circ} \mathrm{C}$ until tested.

Individual fecal samples from all pigs were collected at the same days and stored at $-20^{\circ} \mathrm{C}$ for PCR testing. DNA of fecal was extracted from fecal samples using a commercial kit $^{4}$ according to the manufacturer's protocol, and subsequently tested by PCR (Jones et al. 1993).

Serum and oral fluid analysis. Serum samples were tested by IPMA for anti-L. intracellularis IgG (Guedes et al. 2002b, 2002c). For the verification of titers, positive serum samples at the 1:30 cut-off point were serially diluted to 1:120, 1:480 and 1:1920.

The IPMA used for detection of L. intracellularis-specific IgA and IgG in OF was a modified version of the IPMA used for serum described by Guedes et al. (2002b). The standardization of the IPMA for both isotypes in OF was initially performed on samples from a farm with PPE cases and pigs with high serum antibody titers. To for standardization, briefly, 96-well plates containing acetone fixed monolayer of McCoy cells highly infected with L. intracellularis were rehydrated with distilled water or PBS Tween $0.05 \%$ (PBS with $0.05 \%$ Tween $20, \mathrm{pH} 7.2$ ) for 10 and 45 minutes at $37^{\circ} \mathrm{C}$. OF and secondary antibody (anti-pig $\operatorname{Ig} \mathrm{A}^{5}$ and $\operatorname{IgG}^{6}$-peroxidase conjugate) were diluted in phosphate-buffered saline (PBS; $\mathrm{pH} 7.2$ ), or $0.25 \%$ skimmed milk 1x PBS solution or PBS Tween $0.05 \%$. Secondary antibodies were also diluted in IPMA buffer (PBS with $2.5 \%$ serum

\footnotetext{
3 K675 Dako, Corporation, CarpintariaI. CA 93013 USA.

4 PSP Stool DNA Spin Kit, Molecular STRATEC Campus Berlin-Buch, Germany.

5 Bethyl Laboratories, Montgomery, Texas, USA.

6 Sigma-Aldrich, St. Louis, MO.
} 
fetal bovine, $1 \%$ rabbit serum, and $0.08 \%$ Tween 80 ) (Guedes et al. $2002 \mathrm{~b}$ ). OF were tested undiluted and diluted $1: 2$ and $1: 3$, and the secondary antibodies were tested using 1:45, 1:50, 1:100 and 1:200 dilutions. OF samples were gradually thawed in the refrigerator at $4^{\circ} \mathrm{C}$ for 12 hours to avoid interference of temperature on the integrity of the antibodies (Prickett et al. 2010, Decorte et al. 2013, Jones \& Muehlhauser 2014) and to sediment gross material.

Statistical analysis. Comparisons of serum anti-L. intracellularis IgG, and OF anti- L. intracellularis IgA and IgG between the groups were performed by the Kaplan-Meier test in the statistical program STATA. The level of significance was $5 \%(P<0.05)$. The sensitivity and specificity of IPMA were calculated in Microsoft Excel using the control and infected groups, at $28 \mathrm{dpi}$, for the determination of negative and positive samples, respectively. The Spearman correlation test was used to evaluate the correlation between the detection of serum IgG and IgA and IgG in OF. The Kappa method was used to verify agreement between the tests and the agreement between the detection of specific IgA and IgG in individual and collective samples. The program used was BioEstata 5.0. The pens were considered positive if at least one animal tested positive for the studied immunoglobulin isotype in the individual collection.

\section{RESULTS}

\section{Animals and inoculation}

All pigs were seronegative and PCR negative for Lawsonia intracellularis in fecal samples on day 0 .

In the third week post-inoculation an animal in T2 had bloody diarrhea from 19 to $23 \mathrm{dpi}$, and watery diarrhea until $34 \mathrm{dpi}$, when it was euthanased due to its poor clinical condition and persistent diarrhea. At necropsy, there were typical PPE lesions confirmed by IHC. L. intracellularis fecal shedding was first detected in T2 pigs $7 \mathrm{dpi}$ and peaked at 14 dpi. Pigs in the T1 remained negative up to $28 \mathrm{dpi}$ (Fig.1). At the end of the experiment, macroscopic lesions were more frequent, extensive and severe, as well as IHC scores were more intense in the T1 group.

Four pigs from each group died or were euthanized in the first and second week of the study due to conditions not related to the challenge.

\section{IPMA in serum and oral fluid}

The main modifications of IPMA for OF were the hydration of the plates with PBS Tween $0.05 \%$, no dilution of the samples, and the time of incubation of OF sample was extended to $45 \mathrm{~min}$, as described by Barrera-Zarate (2019). All tested concentrations of anti-pig IgA and anti-pig IgG secondary antibodies were adequate, but the 1:100 dilution in PBS $0.05 \%$ Tween had less background; thus, specific immunostaining was easier to visualize.

One animal in T2 seroconverted $14 \mathrm{dpi}$, and $100 \%$ of the pigs were seropositive at $42 \mathrm{dpi}$. T1 pigs seroconverted at $35 \mathrm{dpi}$, and an increasing number of seropositive pigs were detected at $42 \mathrm{dpi}$, but the proportion of seropositive pigs was significantly lower $(P<0.05)$ than T2 from 14-42 dpi (Fig.1).

The first detection of specific $L$. intracellularis IgA and IgG, respectively, in OF occurred at $14 \mathrm{dpi}$ and $21 \mathrm{dpi}$ in $\mathrm{T} 2$,
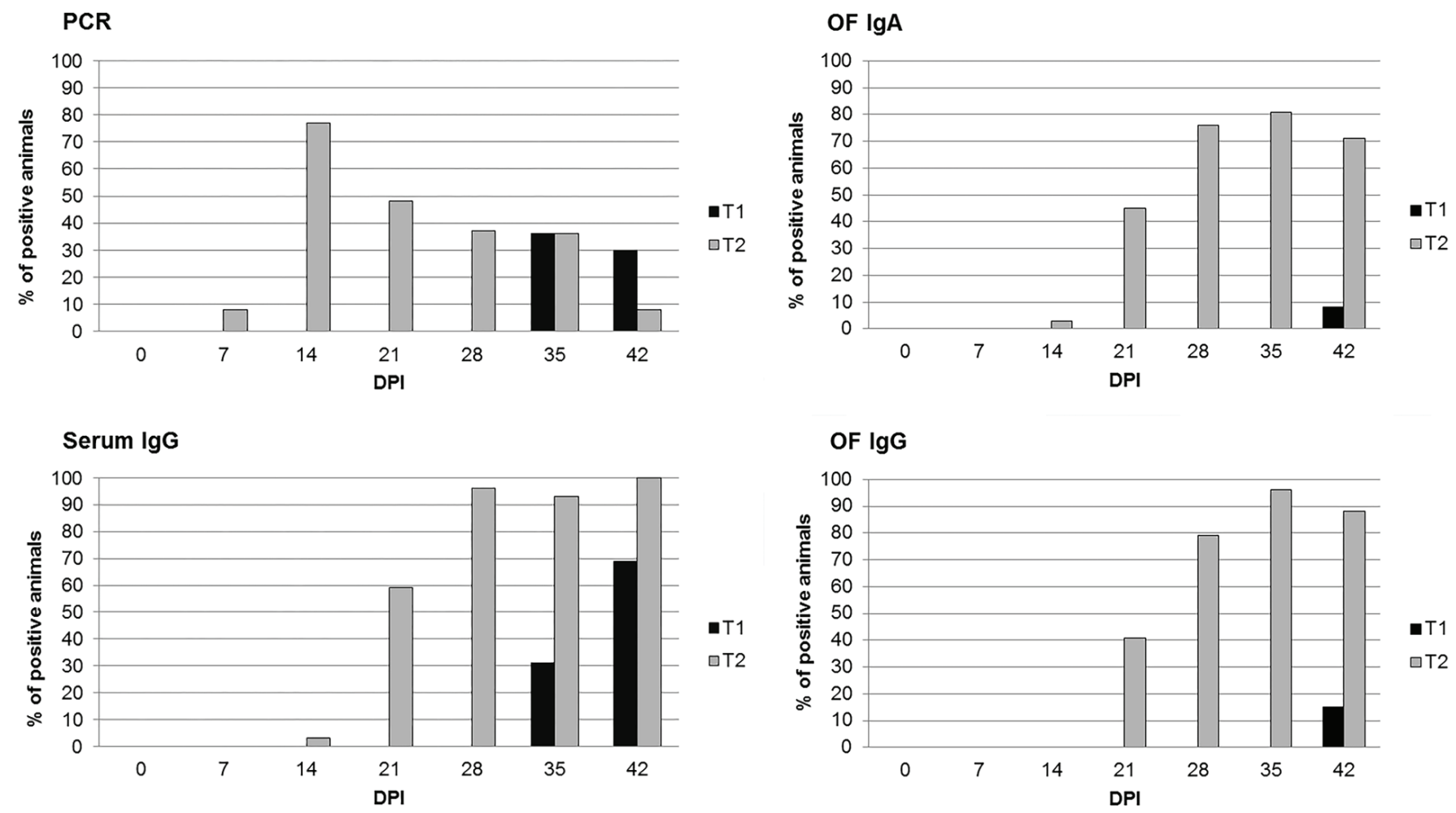

Fig.1. Percentage of positive pigs by PCR for Lawsonia intracellularis in fecal samples, percentage of positive pigs using immunoperoxidase monolayer assay (IPMA) to detect IgG in serum samples and Percentage of positive pigs using IPMA to detect IgA and IgG in oral fluids (OF) samples. All pigs used in the experiment were considered in these analyses. There was a difference $(P<0.05)$ in positive animals for $L$. intracellularis between groups on 7 to $28 \mathrm{dpi}$. There was a difference $(P<0.05)$ in the detection of serum IgG between the groups on 21 to $42 \mathrm{dpi}$. 
with higher percentages of positive pigs at $35 \mathrm{dpi}$ for both isotypes. In T1, both isotypes were detected in OF at $42 \mathrm{dpi}$. The detection of both isotypes in this group remained different from T2 from 14 and 21 dpi until $42 \mathrm{dpi}(P<0.05)$ for IgA and IgG (Fig.2), respectively. Figure 2 shows the curve of serum IgG titers and the percentage of IgA and IgG positive pigs in OF.

The IPMA sensitivity and specificity for the detection of serum IgG and OF IgA and IgG were determined using 52 samples (26 pigs from each group) at $28 \mathrm{dpi}$. The IPMA sensitivity for detecting IgG in serum was $100 \%$ and $84.62 \%$ and $88.46 \%$ for OF IgA and IgG, respectively. The specificity was $100 \%$ for both serum and OF.

There was an increase in the number of IgA- and IgGpositive pigs based on the OF analysis concomitant with the increase in IgG serum titers. There was a high correlation between the detection of serum IgG and the detection of IgA and IgG in the OF ( $\mathrm{rs}=0.82$ and $\mathrm{rs}=0.89$, respectively).

There was high agreement between the IPMA results for specific L. intracellularis IgG in serum and OF IgA and IgG at $28 \mathrm{dpi}$ in individual samples (Table 1). In the OF pen samples, the IPMA detected one positive pig housed together with three negative animals (Table 2 and 3), and there was high agreement between the pen samples IPMA results and the individual animal samples.

\section{DISCUSSION}

The naive condition of the pigs used in this study was confirmed by serology and PCR of samples collected on

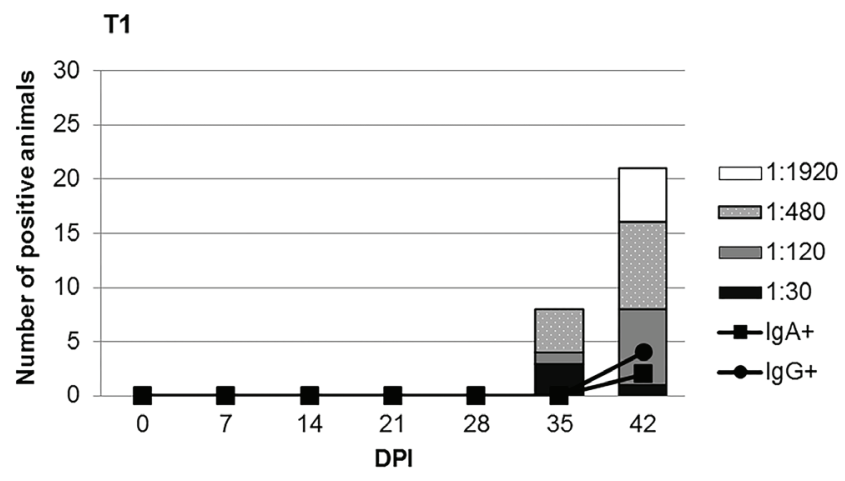

T2

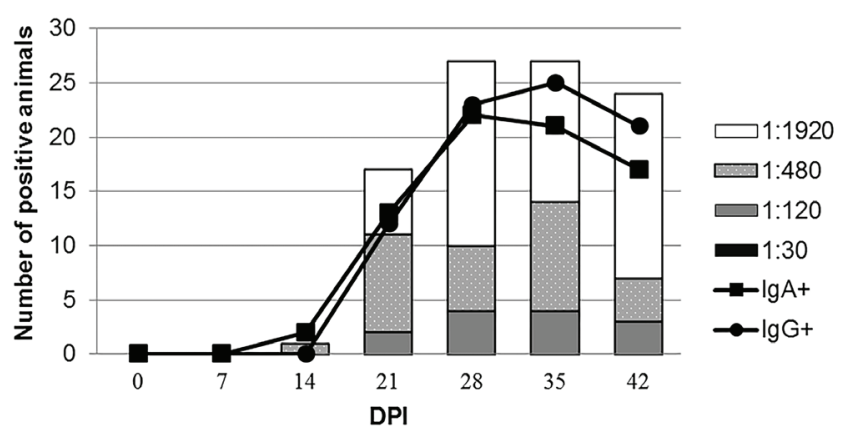

Fig.2. Positivity of pigs detected in serum and oral fluids (OF). Numbers and titers of Lawsonia intracellularis IgG seropositive pigs (bars) and numbers of positive pigs and specific $L$. intracellularis IgA and IgG titers (lines) in OF samples. T1 = control group and T2 = inoculated group. the day of inoculation. The success of the challenge was confirmed by the high number of pigs that shed Lawsonia intracellularis in their feces, the seroconversion rate and the detections of lesions at the end of the experiment. Although the T1 was housed in separate room with strict management, due to the long period of the experiment, there was indirect contamination confirmed by L. intracellularis fecal shedding and seroconversion at $35 \mathrm{dpi}$. This period of T1 contaminations was confirmed with detection of more evident macroscopic lesions and immunolabelling compared to T2. The period between the inoculation of T2 pigs and euthanasia (49 dpi) justify the regression of gross lesions by the end of the trial, as previous demonstrated by Guedes \& Gebhart (2004).

Both clinical manifestations and the detection of $L$. intracellularis in feces of T2 were consistent with other experimental challenge studies using mucosal homogenate as the inoculum (Guedes et al. 2002b, 2002d). Fecal and serum samples from pigs of both groups were negative by PCR and serology during the first two weeks and remained PCR negative until 35 dpi in T1.

Table 1. Percentage of agreement between immunoperoxidase monolayer assay (IPMA) results for specific Lawsonia intracellularis IgG in serum and IgA and IgG in oral fluid (OF) at 21 and $28 \mathrm{dpi}$

\begin{tabular}{lcc}
\hline & $21 \mathrm{dpi}$ & $28 \mathrm{dpi}$ \\
\hline Serum IgG/IgA OF & $79.00^{\mathrm{a}}(0.46)^{\mathrm{b}}$ & $90.38(0.81)$ \\
Serum IgG/IgG OF & $80.77(0.50)$ & $94.23(0.88)$ \\
IgA OF/IgG OF & $86.54(0.58)$ & $92.31(0.84)$ \\
Individual pig IgA/pen IgA & $93.75(0.86)$ & 100.00 \\
Individual pig IgG /pen IgG & 100.00 & 100.00
\end{tabular}

Twenty-six animals were used in each group; ${ }^{a}$ percentage of agreement, ${ }^{\mathrm{b}}$ Kappa-index.

Table 2. Number of positive animals per pen and pan positive for IgA in individual and collective samples, respectively, of pig oral fluid on different days postinoculation with Lawsonia intracellularis

\begin{tabular}{|c|c|c|c|c|c|c|c|c|}
\hline & Pen & $0 \mathrm{dpi}$ & $7 \mathrm{dpi}$ & $\begin{array}{l}14 \\
\text { dpi }\end{array}$ & $\begin{array}{l}21 \\
\text { dpi }\end{array}$ & $\begin{array}{l}28 \\
\text { dpi }\end{array}$ & $\begin{array}{l}35 \\
\text { dpi }\end{array}$ & $\begin{array}{l}42 \\
\text { dpi }\end{array}$ \\
\hline \multirow{8}{*}{$\begin{array}{l}\text { Control } \\
\text { pen }\end{array}$} & $1 \mathrm{~A}$ & $0 / 4$ & $0 / 4$ & $0 / 4$ & $0 / 4$ & $0 / 4$ & $1 / 4$ & $2 / 4$ \\
\hline & $1 \mathrm{~B}$ & $0 / 4$ & $0 / 4$ & $0 / 4$ & $0 / 4$ & $0 / 4$ & $2 / 4$ & $3 / 4^{a}$ \\
\hline & $1 \mathrm{C}$ & $0 / 4$ & $0 / 4$ & $0 / 4$ & $0 / 4$ & $0 / 4$ & $1 / 4$ & $0 / 4$ \\
\hline & 1D & $0 / 4$ & $0 / 4$ & $0 / 4$ & $0 / 4$ & $0 / 4$ & $1 / 4$ & $1 / 4$ \\
\hline & $2 \mathrm{~A}$ & $0 / 3$ & $0 / 2$ & $0 / 2$ & $0 / 2$ & $0 / 2$ & $1 / 2$ & $0 / 2$ \\
\hline & $2 \mathrm{~B}$ & $0 / 3$ & $0 / 2$ & $0 / 2$ & $0 / 2$ & $0 / 2$ & $2 / 2$ & $1 / 2^{\mathrm{a}}$ \\
\hline & $2 \mathrm{C}$ & $0 / 4$ & $0 / 4$ & $0 / 4$ & $0 / 4$ & $0 / 4$ & $1 / 4$ & $0 / 4^{a}$ \\
\hline & $2 \mathrm{D}$ & $0 / 4$ & $0 / 2$ & $0 / 2$ & $0 / 2$ & $0 / 2$ & $0 / 2$ & $1 / 2^{\mathrm{a}}$ \\
\hline \multirow{8}{*}{$\begin{array}{l}\text { Inoculated } \\
\text { pen }\end{array}$} & $3 \mathrm{~A}$ & $0 / 4$ & $0 / 4$ & $1 / 3$ & $3 / 3^{a}$ & $2 / 3^{a}$ & $2 / 2^{\mathrm{a}}$ & $2 / 3^{a}$ \\
\hline & $3 B$ & $0 / 4$ & $0 / 4$ & $1 / 4$ & $2 / 4^{\mathrm{a}}$ & $3 / 4^{\mathrm{a}}$ & $4 / 4^{\mathrm{a}}$ & $4 / 4^{a}$ \\
\hline & $3 \mathrm{C}$ & $0 / 4$ & $0 / 4$ & $0 / 4$ & $1 / 4^{\mathrm{a}}$ & $2 / 4^{a}$ & $1 / 4^{\mathrm{a}}$ & $1 / 4^{a}$ \\
\hline & $3 \mathrm{D}$ & $0 / 4$ & $0 / 4$ & $0 / 4$ & $0 / 4$ & $4 / 4^{a}$ & $4 / 4^{\mathrm{a}}$ & $2 / 4^{a}$ \\
\hline & $4 \mathrm{~A}$ & $0 / 4$ & $0 / 3$ & $0 / 3$ & $0 / 3$ & $1 / 3^{a}$ & $0 / 2^{\mathrm{a}}$ & $0 / 2^{\mathrm{a}}$ \\
\hline & 4B & $0 / 4$ & $0 / 4$ & $0 / 4$ & $3 / 3^{a}$ & $3 / 3^{a}$ & $3 / 3^{a}$ & $3 / 3^{a}$ \\
\hline & $4 \mathrm{C}$ & $0 / 4$ & $0 / 4$ & $0 / 4$ & $3 / 4^{a}$ & $4 / 4^{\mathrm{a}}$ & $3 / 3^{a}$ & $3 / 3^{a}$ \\
\hline & 4D & $0 / 4$ & $0 / 4$ & $0 / 4$ & $1 / 4$ & $3 / 4^{\mathrm{a}}$ & $3 / 4^{a}$ & $2 / 4 a$ \\
\hline
\end{tabular}

a Positive pens in collective oral fluid, ${ }^{\mathrm{b}}$ cells surround indicates pens with negative pens in collective samples, but positive results in individual samples; * Positive in collective sample, but negative in individual samples. 
OF contains pathogens and antibodies derived from serum or produced in tissues associated with the oral cavity. A number of studies in animals have demonstrated the usefulness of OF compared to serum (Pacheco et al. 2010, Pricket et al. 2011, Giménez-Lirola et al. 2013, Vosloo et al. 2015). These studies used ELISA for the detection of serum and OF antibodies. IPMA was chosen in the present study because this methodology was already established in our laboratory and had demonstrated high sensitivity and specificity in previous studies (Guedes et al. 2002b, 2002c).

Similar to serum samples, the present study also demonstrated high specificity of IPMA in OF, as no false positive animal was detected (at 21 and $28 \mathrm{dpi}$ ). Despite the low concentrations of antibodies detectable in OF (Escribano et al. 2012), the IPMA showed moderate sensitivity for detecting IgA (84.62\%) and IgG (88.46\%) in OF. Kittawornrat et al. (2012) also obtained good sensitivity and specificity for the detection of antiPRRSV IgG in field samples after standardization of ELISA in OF. Control pigs showed positive OF after indirect infection, demonstrated by positive PCR and increase of seropositive pigs. This result demonstrated that even naturally infected pigs have detectable antibodies specific for L. intracellularis in the OF. Although not planned, this result demonstrated that this type of sample might also be applicable in field conditions.

Due to IgA antibodies representing mucosal immunity, we expected the detection of IgA prior to IgG, however, as observed that there was no time difference in the detection of both, only two pigs were positive one week before IgG detection in T2. In $\mathrm{T} 2$, the percentage of IgG detection in OF was higher than IgA from 21 to $42 \mathrm{dpi}$. This difference may be explained by the influence of the rope material used (cotton). In two studies using synthetic (i.e., polyamide) and natural fiber (i.e., cotton) rope material, higher detection of IgA was observed using the synthetic materials. However, there was no difference

Table 3. Number of positive animals per pen and pan positive for IgG in individual and collective samples, respectively, of pig oral fluid on different days postinoculation with Lawsonia intracellularis

\begin{tabular}{lcccccccc}
\hline \multirow{5}{*}{ Control } & Pen & $0 \mathrm{dpi}$ & $7 \mathrm{dpi}$ & $\begin{array}{c}14 \\
\mathrm{dpi}\end{array}$ & $\begin{array}{c}21 \\
\text { dpi }\end{array}$ & $\begin{array}{c}28 \\
\text { dpi }\end{array}$ & $\begin{array}{c}35 \\
\text { dpi }\end{array}$ & $\begin{array}{c}42 \\
\text { dpi }\end{array}$ \\
pen & 1A & $0 / 4$ & $0 / 4$ & $0 / 4$ & $0 / 4$ & $0 / 4$ & $0 / 4$ & $1 / 4^{\mathrm{b}}$ \\
& 1B & $0 / 4$ & $0 / 4$ & $0 / 4$ & $0 / 4$ & $0 / 4$ & $0 / 4$ & $1 / 4^{\mathrm{b}}$ \\
& 1C & $0 / 4$ & $0 / 4$ & $0 / 4$ & $0 / 4$ & $0 / 4$ & $0 / 4$ & $0 / 4$ \\
& 1D & $0 / 4$ & $0 / 4$ & $0 / 4$ & $0 / 4$ & $0 / 4$ & $0 / 4$ & $0 / 4$ \\
pen & 2A & $0 / 4$ & $0 / 3$ & $0 / 3$ & $0 / 3$ & $0 / 3$ & $0 / 3$ & $0 / 3$ \\
& 2B & $0 / 3$ & $0 / 2$ & $0 / 2$ & $0 / 2$ & $0 / 2$ & $0 / 2$ & $0 / 2$ \\
& 2C & $0 / 4$ & $0 / 4$ & $0 / 4$ & $0 / 4$ & $0 / 4$ & $0 / 4$ & $1 / 4^{\mathrm{a}}$ \\
& 2D & $0 / 2$ & $0 / 2$ & $0 / 2$ & $0 / 2$ & $0 / 2$ & $0 / 2$ & $1 / 2^{\mathrm{a}}$ \\
& 3A & $0 / 4$ & $0 / 4$ & $0 / 3$ & $2 / 3^{\mathrm{a}}$ & $2 / 2^{\mathrm{a}}$ & $2 / 2^{\mathrm{a}}$ & $2 / 2^{\mathrm{a}}$ \\
& 3B & $0 / 4$ & $0 / 4$ & $0 / 4$ & $1 / 4^{\mathrm{a}}$ & $2 / 3^{\mathrm{a}}$ & $4 / 4^{\mathrm{a}}$ & $4 / 4^{\mathrm{b}}$ \\
& 3C & $0 / 4$ & $0 / 4$ & $0 / 4$ & $1 / 4^{\mathrm{a}}$ & $4 / 4^{\mathrm{a}}$ & $4 / 4^{\mathrm{a}}$ & $3 / 4^{\mathrm{a}}$ \\
& 3D & $0 / 4$ & $0 / 4$ & $0 / 4$ & $0 / 4$ & $4 / 4^{\mathrm{a}}$ & $4 / 4^{\mathrm{a}}$ & $2 / 2^{\mathrm{a}}$ \\
& 4A & $0 / 4$ & $0 / 3$ & $0 / 3$ & $3 / 3^{\mathrm{a}}$ & $1 / 3^{\mathrm{a}}$ & $1 / 2^{\mathrm{a}}$ & $2 / 2^{\mathrm{a}}$ \\
& 4B & $0 / 4$ & $0 / 4$ & $0 / 4$ & $3 / 3^{\mathrm{a}}$ & $3 / 3^{\mathrm{a}}$ & $3 / 3^{\mathrm{a}}$ & $3 / 3^{\mathrm{a}}$ \\
& 4C & $0 / 4$ & $0 / 4$ & $0 / 4$ & $1 / 4^{\mathrm{a}}$ & $4 / 4^{\mathrm{a}}$ & $3 / 3^{\mathrm{a}}$ & $3 / 3^{\mathrm{a}}$ \\
& 4D & $0 / 4$ & $0 / 4$ & $0 / 4$ & $0 / 4$ & $2 / 4^{\mathrm{a}}$ & $4 / 4^{\mathrm{a}}$ & $3 / 4^{\mathrm{a}}$
\end{tabular}

${ }^{a}$ Gray marking indicates the positive pens in collective oral fluid, ${ }^{\mathrm{b}}$ cells surround indicates pens with negative results in collective samples, but positive results in individual samples. between the materials for the detection of IgG (Olsen et al. 2013, Decorte et al. 2014). Another explanation is that sick pigs have higher concentrations of total immunoglobulin in their OF compared to healthy pigs; this is especially true for IgG, which significantly increases among immunoglobulins (Escribano et al. 2012) and remains useful for a longer time in standard concentrations for the diagnosis in both experimental and field samples (Kittawornrat et al. 2012, 2014). Therefore, it can be inferred that the use of cotton rope for the detection IgG anti-L. intracellularis in OF may be used for the monitoring the disease.

The first detection and the peak of antibodies occurred at the same time in the OF and serum in T2 group. Our findings support those Nogueira et al. (2013), who demonstrated that the peak of detection for serum and mucosal IgG against $L$. intracellularis were correlated. A similar correlation between serum and OF IgG was observed in other studies (Prickett et al. 2011, Kittawornrat et al. 2013, Mur et al. 2013). In general, the kinetics of antibodies response in the $\mathrm{OF}$ is dependent on the kinetics of antibodies in the serum and mucosa (Prickett \& Zimmerman 2010). In the present study, there was a significant correlation between the serum IgG and the two isotypes in the OF. The percentage of agreement between the IPMA results in serum and OF was high at $28 \mathrm{dpi}$, with $90 \%$ for IgA and 94\% for IgG. In agreement with our result, Kittawornrat et al. (2013) observed a high correlation between serum and OF and high agreement of positive results using ELISA to detect anti-PRRSV-specific antibodies.

In the present study, the majority of the pigs with IgG titers lower than $<1: 480$ in serum were negative for IgA and IgG in the OF. Similar results were observed in the study of Mur et al. (2013) for African swine fever. The low initial antibody serum titers in control pigs could be explained by the low number of pigs with positive OF one week after IgG seroconversion

Table 4. Number of PCR positive animals per pen in individual fecal collect and qPCR positive pen in collective oral fluids (OF) on different days post-inoculation with Lawsonia intracellularis

\begin{tabular}{lcccccc}
\hline & Pen & $14 \mathrm{dpi}$ & $21 \mathrm{dpi}$ & $28 \mathrm{dpi}$ & $35 \mathrm{dpi}$ & $42 \mathrm{dpi}$ \\
\hline Control pen & 1A & $0 / 4^{\mathrm{a}}$ & $0 / 4^{\mathrm{a}}$ & $0 / 4^{\mathrm{a}}$ & $1 / 4^{\mathrm{a}}$ & $2 / 4^{\mathrm{a}}$ \\
& 1B & $0 / 4^{\mathrm{a}}$ & $0 / 4^{\mathrm{a}}$ & $0 / 4^{\mathrm{a}}$ & $2 / 4^{\mathrm{a}}$ & $3 / 4^{\mathrm{a}}$ \\
& 1C & $0 / 4^{\mathrm{a}}$ & $0 / 4^{\mathrm{a}}$ & $0 / 4^{\mathrm{a}}$ & $1 / 4^{\mathrm{a}}$ & $0 / 4^{*}$ \\
& 1D & $0 / 4^{\mathrm{a}}$ & $0 / 4^{\mathrm{a}}$ & $0 / 4^{\mathrm{a}}$ & $1 / 4^{\mathrm{a}}$ & $1 / 4^{\mathrm{a}}$ \\
& 2A & $0 / 2^{\mathrm{a}}$ & $0 / 2^{\mathrm{a}}$ & $0 / 2^{\mathrm{a}}$ & $1 / 2^{\mathrm{a}}$ & $0 / 2^{*}$ \\
& 2B & $0 / 2^{\mathrm{a}}$ & $0 / 2^{\mathrm{a}}$ & $0 / 2^{\mathrm{a}}$ & $2 / 2^{\mathrm{a}}$ & $1 / 2^{\mathrm{a}}$ \\
Inoculated & 2C & $0 / 4^{\mathrm{a}}$ & $0 / 4^{\mathrm{a}}$ & $0 / 4^{\mathrm{a}}$ & $1 / 4^{\mathrm{a}}$ & $0 / 4^{*}$ \\
& 2D & $0 / 2^{\mathrm{a}}$ & $0 / 2^{\mathrm{a}}$ & $0 / 2^{\mathrm{a}}$ & $0 / 2^{\mathrm{b}}$ & $0 / 2^{*}$ \\
& 3A & $2 / 3^{\mathrm{a}}$ & $1 / 3^{\mathrm{a}}$ & $0 / 3^{\mathrm{a}}$ & $2 / 3^{\mathrm{a}}$ & $0 / 3^{\mathrm{a}}$ \\
& 3B & $2 / 4^{\mathrm{a}}$ & $2 / 4^{\mathrm{a}}$ & $2 / 4^{\mathrm{a}}$ & $2 / 4^{\mathrm{a}}$ & $0 / 4^{\mathrm{a}}$ \\
& 3C & $4 / 4^{\mathrm{a}}$ & $1 / 4^{\mathrm{a}}$ & $1 / 4^{\mathrm{a}}$ & $1 / 4^{\mathrm{a}}$ & $0 / 4^{\mathrm{a}}$ \\
& 3D & $4 / 4^{\mathrm{a}}$ & $2 / 4^{\mathrm{a}}$ & $1 / 4^{\mathrm{a}}$ & $2 / 4^{\mathrm{b}}$ & $0 / 4^{\mathrm{a}}$ \\
& 4A & $2 / 3^{\mathrm{a}}$ & $1 / 3^{\mathrm{a}}$ & $1 / 3^{\mathrm{a}}$ & $0 / 2^{\mathrm{a}}$ & $0 / 2^{\mathrm{a}}$ \\
& 4B & $3 / 4^{\mathrm{a}}$ & $2 / 3^{\mathrm{a}}$ & $1 / 3^{\mathrm{a}}$ & $1 / 3^{\mathrm{a}}$ & $1 / 3^{\mathrm{b}}$ \\
& 4C & $3 / 4^{\mathrm{a}}$ & $3 / 4^{\mathrm{a}}$ & $3 / 4^{\mathrm{a}}$ & $1 / 4^{\mathrm{a}}$ & $0 / 3^{*}$ \\
& 4D & $1 / 4^{\mathrm{a}}$ & $2 / 4^{\mathrm{a}}$ & $1 / 4^{\mathrm{a}}$ & $1 / 4^{\mathrm{a}}$ & $0 / 4^{*}$
\end{tabular}

${ }^{a}$ Gray marking indicates the positive pens in collective oral fluid, ${ }^{\mathrm{b}}$ cells surround indicates pens with negative pens in collective samples, but positive results in individual samples; * Positive in collective sample, but negative in individual samples. 
compared to the inoculated pigs. The difference in the infective initial dose of L. intracellularis (which was presumably lower in the control group due to natural exposure) could explain the difference in the initial immune response of the control pigs, as humoral and mucosal responses are dose dependent (Nogueira et al. 2013).

The application of OF-based testing facilitates the monitoring, surveillance and detection of diseases in animal populations. The samples can be collected from various pigs in pens at the same time, thereby facilitating collection and increasing the sample size (Prickett \& Zimmerman 2010). In a study of the detection of anti-PRRSV-specific antibodies in OF collected in pens, it was observed that IgM, IgG and IgA were readily detected in populations in which the infection was controlled by experimental challenge. However, this was not observed in field samples (Kittawornrat et al. 2012). Natural exposure in the T1 group may have resulted in pigs at different stages of the humoral response. Thus, in the present study, we compared individuals with pen OF to verify whether collective samples could be representative of the group. The results demonstrated high agreement between individual OF and pen OF samples, and IPMA could detect one positive housed together with three negative pigs (Table 2-4).

Similar results were found by Barrera-Zarate et al. (2019) that detected IgG positive oral fluid collected in the pen that not all pigs tested were positive in serum samples. However, just the correlation of positivity of FO and serum was possible in farms with clinical signs, in the growth and finishing pigs.

\section{CONCLUSIONS}

The immunoperoxidase monolayer assay (IPMA) technique has demonstrated moderate sensitivity and high specificity for the detection of anti-Lawsonia intracellularis IgA and IgG in oral fluids (OF) in experimentally inoculated pigs and has the ability to detect positive pigs in OF pen samples.

The simultaneous detection of antibodies in both serum and OF samples and the high agreement between the IPMA in serum and OF demonstrate that OF may be used for serologic profile analysis, but not for individual diagnosis of EPS.

In addiction, IgG antibodies remain in the oral fluid for a minimum of three weeks.

\footnotetext{
Acknowledgements.- The authors thank "Pró de Reitoria de Pesquisa” of the "Universidade Federal de Minas Gerais" (PRPq-UFMG), "Conselho Nacional de Desenvolvimento Científico e Tecnológico" (CNPq), "Coordenação de Aperfeiçoamento de Pessoal de Nível Superior" (CAPES) and "Fundação de Amparo à Pesquisa do Estado de Minas Gerais" (Fapemig) for their financial support. R.M.C.G. is a recipient of a fellowship from CNPq. Rafaela Andrade collaborated with processed samples. João Paulo Haddad collaborated with data analysis.
}

Conflict of interest statement.- The authors declare that there is no conflict of interest.

\section{REFERENCES}

Barrera-Zarate J.A., Andrade M.R., Pereira C.E.R., Vasconcelos A., Wagatsuma M.M., Sato J.P.H., Daniel A.G.S., Rezende L.A., Otoni L.A.V., Laub R.P., Macedo N.R., Costa C.M., Haddad J.P.A. \& Guedes R.M.C. 2019. Oral fluid for detection of exposure to Lawsonia intracellularis in naturally infected pigs. Vet. J. 244:34-36. <https://dx.doi.org/10.1016/j.tvjl.2018.12.003> $<$ PMid:30825892>
Decorte I., Breedam W.V., Stede Y.V., Nauwync H.J., Regge N.D. \& Cay A.B. 2014 Detection of total and PRRSV-specific antibodies in oral fluids collected with different rope types from PRRSV-vaccinated and experimentally infected pigs. BMC Vet. Res. 10:134. <https://dx.doi.org/10.1186/17466148-10-134><PMid:24938323>

Decorte I., Van der Stede Y., Nauwynck H., De Regge N. \& Cay A.B. 2013. Effect of saliva stabilisers on detection of porcine reproductive and respiratory syndrome virus in oral fluid by quantitative reverse transcriptase real-time PCR. Vet. J. 197(2):224-228. <https://dx.doi.org/10.1016/j.tvjl.2013.02.001> $<$ PMid:23489844>

Escribano D., Gutiérrez A.M., Martínez Subiela S., Tecles F. \& Cerón J.J. 2012. Validation of three commercially available immunoassays for quantification of IgA, IgG, and IgM in porcine saliva samples. Res. Vet. Sci. 93(2):682-687. <https://dx.doi.org/10.1016/j.rvsc.2011.09.018><PMid:22019471>

Giménez-Lirola L.G., Xiao C.T., Zavala M., Halbur P.G. \& Opriessnig T. 2013. Improving ante mortem diagnosis of Erysipelothrix rhusiopathiae infection by use of oral fluids for bacterial, nucleic acid, and antibody detection. J. Microbiol. Methods 92(2):113-121. <https://dx.doi.org/10.1016/j. mimet.2012.11.014><PMid:23201482>

Guedes R.M.C. \& Gebhart C.J. 2003a. Preparation and characterization of polyclonal and monoclonal antibodies against Lawsonia intracellularis. J. Vet. Diagn. Invest. 15(5):438-446. <https://dx.doi.org/10.1177/104063870301500506> <PMid:14535543>

Guedes R.M.C. \& Gebhart C.J. 2004. Progression of L. intracellularis infection and mucosal immune response in pigs. Proceedings of the International Pig Veterinary Society, 18th International Pig Veterinary Society, Congress Hamburg, Germany, p.250.

Guedes R.M.C. 2007. Diarreias e enterites em leitões de recria e terminação. Suinocultura, Proceedings of the AveSui Regiões, VII Seminário de Aves e Suínos, Belo Horizonte, MG, p.39-43.

Guedes R.M.C., Gebhart C.J., Armbruster G.A. \& Roggow B.D. 2002d. Serologic follow-up of a repopulated swine herd after an outbreak of proliferative hemorrhagic enteropathy. Can. J. Vet. Res. 66(4):258-263.<PMid:12418781>

Guedes R.M.C., Gebhart C.J., Deen J. \& Winkelman N.L. 2002b. Validation of an immunoperoxidase monolayer assay as a serologic test for porcine proliferative enteropathy. J. Vet. Diagn. Invest. 14(6):528-530 <https://dx.doi.org/10.1177/104063870201400618><PMid:12423042>

Guedes R.M.C., Gebhart C.J., Winkelman N.L. \& Mackie-Nuss R.A. 2002c. A comparative study of an indirect fluorescent antibody test and an immunoperoxidase monolayer assay for the diagnosis of porcine proliferative enteropathy. J. Vet. Diagn. Invest. 14(5):420-423. <https://dx.doi.org/10.1177/104063870201400512><PMid:12296397>

Guedes R.M.C., Gebhart C.J., Winkelman N.L., Mackie-Nuss R.A.C., Marsteller T.A. \& Deen J.2002a. Comparison of different methods for diagnosis of Porcine Proliferative Enteropathy. Can. J. Vet. Res. 66(2):99-107. <PMid:11989741>

Jones G.F., Ward G.E., Murtaugh M.P., Lin G. \& Gebhart C.J. 1993. Enhanced detection of intracellular organism of swine proliferative enteritis, Ileal symbiont intracellularis, in faeces by polymerase chain reaction. J. Clin. Microbiol. 31(10):2611-2615. <https://dx.doi.org/10.1128/JCM.31.10.26112615.1993><PMid:8253956>

Jones T.H. \& Muehlhauser V. 2014. Effect of handling and storage conditions and stabilizing agent on the recovery of viral RNA from oral fluid of pigs. J. Virol Methods 198:26-31. <https://dx.doi.org/10.1016/j.jviromet.2013.12.011> $<$ PMid:24384096>

Kittawornrat A., Engle M., Panyasing Y., Olsen C., Schwartz K., Rice, A., Lizano S., Wang C. \& Zimmerman J. 2013. Kinetics of the porcine reproductive and respiratory syndrome virus (PRRSV) humoral immune response in swine serum and oral fluids collected from individual boars. BMC Vet. Res. 9:61.<https://dx.doi.org/10.1186/1746-6148-9-61><PMid:23537175>

Kittawornrat A., Panyasing Y., Goodell C., Wang C., Gauger P., Harmon K., Rauh R., Desfresne L., Levis I. \& Zimmerman J. 2014. Porcine reproductive and respiratory syndrome virus (PRRSV) surveillance using pre-weaning 
oral fluid samples detects circulation of wild-type PRRSV. Vet. Microbiol. 168(2/4):331-339. <https://dx.doi.org/10.1016/j.vetmic.2013.11.035> $<$ PMid:24393634>

Kittawornrat A., Prickett J., Wang C., Olsen C., Irwin C., Panyasing Y., Ballagi A., Rice A., Main R., Johnson J., Rademacher C., Hoogland M., Rowland R. \& Zimmerman J. 2012. Detection of porcine reproductive and respiratory syndrome virus (PRRSV) antibodies in oral fluid specimens using a commercial PRRSV serum antibody enzyme-linked immunosorbent assay. J. Vet. Diagn. Invest. 24(2):262-269.<https://dx.doi.org/10.1177/1040638711435679> $<$ PMid:22379043>

Kroll J.J., Roof M.B., Hoffman L.J., Dickson J.S. \& Harris D.L. 2005 Proliferative enteropathy: a global enteric disease of pigs caused by Lawsonia intracellularis. Anim. Health Res. Rev. 6(2):173-197. <https://dx.doi.org/10.1079/ ahr2005109><PMid:16583781>

McOrist S., Gebhart C.J., Boid R. \& Barns S.M. 1995. Characterization of Lawsonia intracellularis gen. nov., sp. nov., the obligately intracellular bacterium of porcine proliferative enteropathy. Int. J. Syst. Bacteriol. 45(4):820-825. <https://dx.doi.org/10.1099/00207713-45-4-820><PMid:7547305>

Mur L., Gallardo C., Soler A., Zimmermman J., Pelayo V., Nieto R., SánchezVizcaíno J.M. \& Arias M. 2013 Potential use of oral fluid samples for serological diagnosis of African swine fever. Vet. Microbiol. 165(1/2):135-139. <https://dx.doi.org/10.1016/j.vetmic.2012.12.034><PMid:23374655>

Nogueira M.G., Collins A.M., Donahoo M. \& Emery D. 2013. Immunological responses to vaccination following experimental Lawsonia intracellularis virulent challenge in pigs. Vet. Microbiol. 164(1/2):131-138. <https://dx.doi.org/10.1016/j.vetmic.2013.02.004><PMid:23478250>

Olsen C., Karriker L., Wang C., Binjawadagi B., Renukaradhya G., Kittawornrat A., Lizano S., Coetzee J., Main R., Meiszberg A., Panyasing Y. \& Zimmerman J. 2013. Effect of collection material and sample processing on pig oral fluid testing results. Vet. J. 198(1):158-163. <https://dx.doi.org/10.1016/j. tvjl.2013.06.014><PMid:24011474>

Ouyang K., Binjawadagi B., Kittawornrat A., Olsen C., Hiremath J., Elkalifa N. Schleappi R., Wu J., Zimmerman J.J. \& Renukaradhya G. 2013 Development and validation of assay to detect porcine reproductive and respiratory syndrome virus-specific neutralizing antibody titers in pig oral fluid samples. Clin. Vaccine Immunol. 20 (8):1305-1313. <https://dx.doi.org/10.1128/ CVI.00276-13><PMid:23784856>

Pacheco J.M., Butler J.E., Jew J., Ferman G.S., Zhu J. \& Golde W.T. 2010. Iga antibody response of swine to Foot-and-Mouth Disease virus infection and vaccination. Clin. Vaccine Immunol. 17(4):550-558. <https://dx.doi. org/10.1128/CVI.00429-09><PMid:20107003>
Panyasing Y., Goodell C.K., Giménez-Lirola L., Kittawornrat A., Wang C., Schwartz K.J. \& Zimmerman J.J. 2013. Kinetics of influenza A virus nucleoprotein antibody IgM, IgA, and IgG in serum and oral fluid specimens from pigs infected under experimental conditions. Vaccine 31(52):6210-6215. <https://dx.doi.org/10.1016/j.vaccine.2013.10.040><PMid:24200976>

Panyasing Y., Goodell C.K., Wang C., Kittawornrat A., Prickett J.R., Schwartz K.J., Ballagi A., Lizano S. \& Zimmerman J.J. 2014. Detection of influenza A virus nucleoprotein antibodies in oral fluid specimens from pigs infected under experimental conditions using a blocking ELISA. Transbound. Emerg. Dis. 61(2):177-184. <https://dx.doi.org/10.1111/tbed.12019> $<$ PMid:23046061>

Prickett J., Simer R., Christopher-Hennings J., Yoon K.J., Evans R.B. \& Zimmerman J.J. 2008. Detection of Porcine reproductive and respiratory syndrome virus infection in porcine oral fluid samples: a longitudinal study under experimental conditions. J. Vet. Diagn. Invest. 20(2):156-163. <https://dx.doi.org/10.1177/104063870802000203><PMid:18319427>

Prickett J.R. \& Zimmerman J.J. 2010. The development of oral fluid-based diagnostics and applications in veterinary medicine. Anim. Health Res. Rev.11(2):207-216. <https://dx.doi.org/10.1017/S1466252310000010> <PMid:20202287>

Prickett J.R., Cutler S., Kinyon J.M., Naberhaus N., Stensland W.R., Yoon K.-J. \& Zimmerman J.J. 2010. Stability of porcine reproductive and respiratory syndrome virus and antibody in swine oral fluid. J. Swine Health Prod. 18(4):187-195.

Prickett J.R., Johnson J., Murtaugh M.P., Puvanendiran S., Wang C., Zimmerman J.J. \& Opriessnig T. 2011. Prolonged detection of PCV2 and anti-PCV2 antibody in oral fluids following experimental inoculation. Transbound. Emerg. Dis. 58(2):121-127.<https://dx.doi.org/10.1111/j.1865-1682.2010.01189.x> <PMid:21223532>

Vannucci F.A., Pusterla N., Mapes S.M. \& Gebhart C. 2012. Evidence of host adaptation in Lawsonia intracellularis infections. Vet. Res. 43(1):53. <https:// dx.doi.org/10.1186/1297-9716-43-53><PMid:22715937>

Vosloo W., Morris J., Davis A., Giles M., Wang J., Nguyen H.T., Kim P.V., Quach N.V., Le P.T., Nguyen P.H., Dang H., Tran H.X., Vu P.P., Hung V.V., Le Q.T., Tran T.M., Mai T.M., Le Q.T. \& Singanallur N.B. 2015. Collection of oral fluids using cotton ropes as a sampling method to detect Foot-and-Mouth Disease virus infection in pigs. Transbound. Emerg. Dis. 62(5):e71-75. <https://dx.doi. org/10.1111/tbed.12196><PMid:24325543>

Walter D., Gebhart C., Kroll J., Holck J.T. \& Chittick W. 2004. Serologic profiling and vaccination timing for Lawsonia intracellularis. J. Swine Health Prod. 12(6):310-313. 